\title{
HEALTH CARE REFORM IN AMERICA: BEYOND IDEOLOGY
}

\author{
Professor George J. Annas* \\ Recipient of the McDonald-Merrill-Ketcham \\ Memorial Award for Excellence in Law and Medicine
}

March 19, 2008

EDITOR's NOTE

The inspiration for the following keynote address was drawn from an article authored by Professor Annas in 1995 which appeared in the New England Journal of Medicine. ${ }^{2}$ In that article, Professor Annas sought to explain the Clinton healthcare plan's failure by analyzing the power and importance of the healthcare reform metaphors used in promoting the plan. In his remarks here, Professor Annas extends his analysis of healthcare related metaphors to those common in current healthcare reform parlance, theorizing that current efforts at healthcare reform have been unsuccessful, in part, because the metaphors used fail to frame the issues involved in a way that the American people can identify with.

* Professor Annas is the Edward R. Utley Professor and Chair of the Department of Health Law, Bioethics \& Human Rights at Boston University School of Public Health and a professor at the Boston University School of Medicine and School of Law. He is the co-founder of Global Lawyers and Physicians, a transnational professional association of lawyers and physicians working together to promote human rights and health. He has a JD from Harvard Law School and an MPH from Harvard School of Public Health. After graduating from law school, he clerked for Justice John V. Spalding of the Massachusetts Supreme Judicial Court and came to Boston University in 1972 as the Director of the Center for Law and Health Sciences at the law school. The author or editor of 16 books on health law and bioethics, including The Rights of Patients, and American Bioethics, Professor Annas has been called "the father of patient rights," "the doyen of American medico-legal analysts," and a "national treasure." $\mathrm{He}$ is a fellow of the American Association for the Advancement of Science, a member of the Institute of Medicine, co-chair of the American Bar Association's Committee on Health Rights and Bioethics, and a member of the Committee on Human Rights of the National Academies. He has also held a variety of governmental regulatory posts, including Vice Chair of the Massachusetts Board of Registration in Medicine, Chair of the Massachusetts Health Facilities Appeals Board, and Chair of the Massachusetts Organ Transplant Task Force. Copyright 2008 by George J. Annas.

2. George J. Annas, Reframing the Debate on Health Care Reform by Replacing Our Metaphors, 332 NEW ENG. J. MED. 745, 745-48 (1995). 


\section{TRANSCRIPT OF KEYNOTE ADDRESS}

MR. ANNAS: Ernest Hemingway wrote a complaining letter to Faulkner after Faulkner had reviewed The Old Man and the Sea and gave it a poor review. Hemingway told Faulkner that it wasn't right to criticize him. He wrote, "Writers should stick together like doctors and lawyers and wolves." When asked about that he said, he didn't mean to demean the wolves. The wolves are great. These professions really stick together and support each other. He said he really admired that about doctors and lawyers.

In the old days, all you had to know about being a physician was contained in the Boy Scout Law. I don't know if there are any old Boy Scouts here. If there are, you know a Scout is: trustworthy, loyal, helpful, friendly, courteous, kind, obedient, cheerful, thrifty, brave, clean, and reverent, right? You have to be a Boy Scout to say that fast, but you don't have to be a Boy Scout to know the first six are what we want from our doctors - to be trustworthy, loyal, helpful, friendly, courteous, and kind. And the last six are what our doctors what from us - to be obedient, cheerful, thrifty, brave, clean, and reverent. For good or evil, medicine, especially its technologically-driven nature and its increasing ability to identify and cure disease, has become much more complicated, making it difficult for Americans to even agree on how to talk about it.

The last time the country got into a major discussion about healthcare was back in the early days of the Clinton Administration with the Clinton healthcare plan. Before that it was the Medicare and Medicaid discussion in the days of Lyndon Johnson. Hopefully this year we will begin another national discussion. We usually talk about healthcare every twenty years in this country, so we're doing it a little sooner than normal, but it won't come around again, unless the whole system collapses, for another ten or twenty years. So this is our big opportunity to try to get it right, and we should be thinking about what went wrong last time.

The three major problems with healthcare have always been - cost, quality, and access, specifically, containing costs, improving quality, and expanding access. That's not a revelation to anybody. We always talk about cost, quality, and access. Most of the time lately, we've been talking exclusively about cost, and for good reason. Current healthcare costs in America are over $\$ 2$ trillion, $\$ 7500$ a person, twice as much as most other countries spend, and ever increasing at a rate usually at least double the annual consumer price index. So cost is a big deal, but quality is not irrelevant and certainly neither is access. They're all central issues, and I've argued before that you can't effectively deal with them separately. You have to deal with all three at the same time or any progress you make in one area is lost in another area. Perhaps the only exception to this rule is eliminating or reducing harmful and unnecessary medical procedures. 
When Hillary first and then Bill Clinton gave their two main speeches on healthcare introducing their healthcare plan, they both said that the plan was based on what they called six guiding stars: security, savings, quality, responsibility, choice, and simplicity. And what you knew, if you took them seriously and if they took themselves seriously, is if these were the guides to flesh out their plan, then it was doomed to failure from the beginning. That's because these six are not only mutually inconsistent, they are also derived from totally different metaphors, and some of them, especially responsibility, are downright un-American.

Let's look at them quickly. First, security. I always thought security was strange in this context, but I was wrong and Bill Clinton was right. Americans crave security. We really like security a lot - especially post-9/11 national security, and homeland security. You can go back to FDR and have Social Security. So security was right. Even though it adopts the military metaphor, as we'll talk about.

As for savings, you're not going to get savings in expanding access to healthcare, so it's a little weird to talk about savings. Maybe there is some waste in the system, and certainly administrative costs can be cut, but as a general matter broadening access - at least in the absence of draconian rationing, will cost more money.

Quality is, like cost and access, one of the traditional big three. We always say quality when we talk about healthcare. We want quality healthcare. So there is nothing wrong with saying it again here, although you can't save money by improving quality.

Responsibility is, as I've already suggested, almost un-American. We don't take responsibility for anything in this country, either as a country or as individual citizens. We live as we please (that's the "American way of life"), and expect our physicians to take care of us if our lifestyles lead to injury or disease.

Choice is good, even central to being an American. Liberty is great, and Americans love choice; although we'll have to ask, choice of what?

Finally, simplicity: Simplicity is, I think, a cruel joke. Whatever our current system (or non-system as most analysts prefer to denote it) is, it is extraordinarily complex - as was the Clinton plan.

Harry and Louise, two characters created as spokespersons for the health insurance industry, starred in a series of commercials opposing the Clinton plan - some of you may remember these - with the catch phrase, "They choose, we lose." The Clintons responded with a spoof about the Harry and Louise series. It was one of the funniest things I ever saw, but the Clintons came quickly to believe that it could be counterproductive, and shut it down. I don't know if it's on YouTube, but I've never seen it again. At one point in their Harry and Louise spoof, Hillary says to Bill, "You know, at page 27,655 of your healthcare plan, it says eventually we all die." To which Bill responds, "There's got to be a better way." And in a way we all think that. We know we're going to die, but we don't confront it in this country. We deny death, and at some level 
expect American medicine to save us from it by coming up with a "medical miracle."

Sam Donaldson said, as soon as he saw the Clinton exchange, that they should get rid of it immediately because if you ever talk about death in the United States, that's the end of your campaign. In his view - and he may be right - politicians can't talk about death in the U.S.

The other thing that happened, this was a coincidence, but I think is still relevant to our discussion. On the very day in September, 1994 that Bill Clinton withdrew his healthcare plan from the U.S. Senate, the first episode of $E R$ was aired in the United States. The program is still going on, and is the longest-lived medical series in U.S. television history. Why is that? Is it because, as Newsweek says, that's "a health program that really works?" Is it because it focuses on sex and violence? Or is it because emergency care is the only care that Americans have a legal right to - which I think is at the core of its popularity (there are lots of other programs featuring sex and violence). Americans really, really like knowing that they can get emergency care when they need it. They like at least a limited legal right to healthcare, a right to emergency care. No way you can take that away. It's been tried. It's very difficult even to close your emergency room department.

Americans really like the fact, as portrayed on the show, that whenever someone got to the emergency department, they were taken care of. They were taken care of based on what was wrong with them, not based on how much money they had or the insurance plan they had, what race they were, or what their occupation was. They were taken care of because they were sick or injured and needed care. And I do believe that the overwhelming majority of Americans believe that's the way it should be, that people should have a right to healthcare, not just a right to emergency care, and that we're struggling with a way to actualize that right without breaking the bank, and without interfering with choice.

So that's a big deal, and I don't want you to forget that. Americans believe in the right to emergency care. And that could be generalized, I think, to the right to healthcare, at least what we might call basic healthcare or decent healthcare. We have to figure out what that means, of course, and it's not easy. And that's where metaphors can help us, and are probably necessary. So we're going to talk about metaphors. The most famous metaphor in the last couple weeks in the United States has been the red phone. And what does that mean? What is it a metaphor for? It suggests that the next president will have to be able to answer an emergency call in the middle of the night and make a decision. But what does it stand for? Is it experience? Is it 9/11? What does that metaphor stand for?

The point is that metaphors use something else to stand for a thing that it's not. So when we talk about healthcare in military terms, we use military images to displace or explain healthcare. Most often we use metaphors as a mirror, as a way to see something and give us more information about what the thing is really like. My body is my house, for example, and I should maintain it and take 
care of it. But sometimes metaphors can be subversive; we can use it to undermine reality. The essence of the person is the brain (therefore if we can maintain the brain - in or out of the body - we maintain the person, perhaps immortally. And sometimes they can be transformative; we use them to try to transform reality and make it into something different. The body is a complex of parts, like a jigsaw puzzle, so if one part is destroyed or diseased, we can replace it. Metaphors are complicated things, and you can decide for yourself, as many Americans are, what the red phone stands for, and how you relate to that, and how that relates to the candidates, and what we should think about that. But by discussing the red phone publicly, Americans will also come to a consensus on what it "means."

In healthcare, when we talk about emergencies, we talk about emergency care. When we talk about emergencies in the United States, we know it's much more complicated than that, especially since $9 / 11$ as we have adopted more and more national security metaphors which have even infected medicine and public health. One of my favorite examples is the bird flu scare of two years ago (Scientists tell us nothing's changed in two years. We're at exactly the same risk for a global pandemic of bird flu today as we were two years ago). Two years ago when the Government tried to get all Americans extremely excited and fearful about bird flu, the President literally said he was ready to call out the Army to barricade and quarantine off parts of the United States if a bird flu pandemic started here. One of the stupidest ideas ever, but nonetheless, it showed how his Administration felt about the bird flu - a national security problem that demanded military intervention.

It turns out, Americans are not afraid of chickens. I mean that literally. We're afraid of lots of things since 9/11, but you can't get Americans excited about the flu or birds. On the other hand, something that's a lot less scary got Americans half hysterical: SARS. And you can ask yourself what's the difference between SARS and the bird flu - besides the birds that is. And it has something to do with where it came from - although likely the bird flu would come from somewhere in Asia as well - and that it's mysterious, unknown and unfamiliar. We really didn't know what it was, or how it spread, and had no cures, and no treatments. At least we had some treatments for the flu. Even though 40,000 Americans die of the flu every year and no Americans have ever died of SARS. So we get afraid of different things for different reasons, mostly having nothing to do with rationality or probabilities. And it helps us, I think, to try to figure out why we react to some emergencies, like a medical emergency, with compassion and a belief that we should have a law about that everybody should have the right to emergency treatment. But for other treatments, such as treatments for chronic diseases, the American public sees it, apparently, through a totally different lens.

Of course, the scariest thing in the world is a lawyer with a contagious disease. Andrew Speaker, a TB patient, was, for a few days at least, the scariest person in the world. The frightening thing he did was take a plane to get married in Europe and then successfully evade the CDC which was publicly trying 
to track him down and quarantine him. He was the first sick person ever to be put on the anti-terrorist no-fly list. So we treated Andrew Speaker exactly like a bioterrorist. Even though it turns out he was misdiagnosed, and didn't put anybody at risk ever. Nonetheless, he's still stared at. This guy has said he still can't really go out and walk around the community, even though he is not and never was contagious. The only person he would likely have ever infected is his fiancée, and obviously that's the last thing he really wanted to do. Nonetheless, he's an example of how we can personalize and stigmatize and try to blame individuals for giant public health problems that we have done all-toolittle to resolve, and that they are victims of, not perpetrators of. Speaker had nothing to do with the epidemic of TB around the world. The fact that he was a lawyer being pursued by physicians also makes this too good a story not to recount in a law-medicine lecture.

All right, now let's look directly at metaphors in medicine - finally I'm sure you're thinking. Probably the best work that's ever been done on metaphors in medicine was done by Susan Sontag in two of her books. Illness as Metaphor, published in 1977, is about her bout with breast cancer and her realization, as a cancer patient, that cancer is used pervasively throughout society as a metaphor, and not a metaphor for good things either; and that it stigmatizes cancer patients by making them feel extremely ostracized and not part of the human race. Secondly, there are lots of other metaphors she found out besides using cancer as a metaphor. Medicine adopts lots of metaphors itself which have negative impacts on patients. Especially she talks about the military metaphor, which we will talk about in a second.

In Illness as Metaphor she also wrote about plague and epidemic metaphors, which she expected to recede as medicine became more adept. But with the rise of AIDS after her first book, she wrote another book, AIDS and its $\mathrm{Me}$ taphors. It turned out actually, that HIV/AIDS metaphors were all plague related metaphors that stigmatized patients, tended to plague patients for their own disease, and tended to also adopt the military metaphor again. Andrew Speaker is a good example of an individual demonized by the plague metaphor.

So I want to give Susan Sontag total credit for beginning this dialogue, at least in the public sphere. Others have written about metaphors in medicine too, but I think she wrote the best books. The first metaphor she explains is the military metaphor, and you're all familiar with the military metaphor whether you've thought about its use or not. Because we're always doing battle, we're always fighting disease. The disease invades the body and using our armamentaria, using our smart weapons, using everything that we can throw at it we try to defeat the enemy, and in the battle for life, it sometimes becomes unclear who the enemy is. Sometimes the patient's body itself is seen as the battlefield. You can't obviously win the battle and lose the war by killing the patient, literally killing the patient (although we have the old joke, the operation was a success, but the patient died). And it can also be unconditional warfare in the sense that you can be seen even as fighting good versus evil, fight to the death, if you will, and in those kind of fights, anything goes. Literally anything goes, 
we follow Shakespeare, desperate diseases require desperate remedies. And the metaphor gets used a lot in things like bone marrow transplants, where you have to literally kill the bone marrow in a patient and try to resurrect it. So again, Sontag argues and other people have argued that military metaphors tend to make us over mobilize, tend to say there are no limits, to spend and do whatever's necessary for victory.

The noted Princeton economist, Uwe Reinhardt, has pointed out that medicine and the military are the only sectors in which we will pay $100 \%$ more for something that's $1 \%$ more effective. Every other sector pays $1 \%$ more for $1 \%$ better, but in the military and in medicine we'll pay $100 \%$ more, probably even $1000 \%$ more for something that's a little bit better, because we are thinking about survival and life is "priceless." We've seen this most dramatically in some of the "new" cancer drugs that may not even prolong survival, but can keep a tumor from growing for a few months. Those drugs produce revenues of literally billions of dollars right now.

So the body is a battlefield, and the military metaphor tends let physicians to do things to patients that I would argue they shouldn't do. Again, Sontag thought that metaphor would go away by now, thought we'd be done with it by now. But we're not, at least not entirely. But its dominance has receded as we have latched on to a newer metaphor. After the Clinton plan failed, the new metaphor in medicine, the prime metaphor, was the market metaphor. And it remains dominant. We don't have patients anymore, we have consumers; we don't have hospitals or specializations anymore; we have product lines; we engage in advertising to gain market share in covered lives. We spend a lot of time in mergers and acquisitions, and corporations, both for-profit and not-forprofit, tend to be much more interested in a healthy bottom line than a healthy population.

The market metaphor has been very pervasive, and it feeds into lots of heavy-duty American values, like freedom (as in free market) and choice. The market metaphor is perfect for choice, even though in the Harry and Louise commercials, it was choice of doctor. That's what they were worried about. They're going to take away our choice of physicians. Turns out Americans really were worried about that. The choice the healthcare insurance market offers, however, is the choice of health plans (at least for those who can afford the premiums), insurance plans, choice of insurance, and it does lead us to know that even on the national level we tend to use interchangeably the words "national healthcare" and "national health insurance." Hopefully insurance will provide access to care, but not necessarily. Those two things are different, and while there are many European countries that have national health insurance, there are also countries like England that have national care with no insurance at all. Everybody just has access to care. They cut out the middle man. We can argue about that, but every dollar of expenses in healthcare, a little over $\$ 2$ trillion annually and growing, is somebody's dollar of income, and they will fight to retain it. The Clintons found that out lots of times. 
Well, is there another metaphor that we can use if these two tend to promote excess spending without providing universal coverage or access? I think there is. I suggested in 1995 that the ecological metaphor is necessary and that we should at least consider as an alternative. Ecology has not been that strong a point for our country, though we see some possible shifts lately. Ecologists think in terms of sustainability, and at least some public officials are now starting to think about it. Even in my own state of Massachusetts with our new mandate program. Therese Murray, our Speaker of the Senate, just said two weeks ago, that Massachusetts will have to make some fundamental changes to healthcare if our plan is going to be "sustainable." So she adopted sustainability, and she's right. Sustainability is a requirement to any meaningful health care reform. Also, quality of life, and quality of the environment are important concepts, more important, I think, than quantity of life or quantity of consumption. Natural and renewable are also important concepts. All of those elements of the environmental metaphor may lead us to think in new ways about healthcare. Even to think about that horrible word in the United States, limits. We don't have to think about rationing right away, but there might be some limits to how much we should spend, how much medical treatment we should provide to individual patients.

The healthcare system has been called lots of things by lots of people, but train wreck and shipwreck are the terms that are commonly used to describe the healthcare system. It's thought that we're not going to change it until it implodes or collapses, until we experience a real national emergency. A few weeks ago policy expert Lawrence Brown wrote a very nice piece in the $\mathrm{New}$ England Journal of Medicine where he argued that we don't have two healthcare systems like we've always thought about, a public and a private one. We really have three healthcare systems, and he thinks that explains why the system has not imploded yet. And he may be right. He used another powerful metaphor, what we call the "safety net." We have the public system - Medicare, Medicaid, VA, the military hospitals - the private system, everybody else, and the safety net, the uncoordinated system of emergency departments, community health centers, and public health clinics. So we all have convinced ourselves that because the "safety net" exists, we really don't have to provide health insurance for the forty-seven million people without insurance, or better insurance for the fifty million who are underinsured - the safety net will take care of them.

One of the people who commented on a presentation I gave in Texas a couple months ago said to me - and it's mostly true - "Well, how bad can it be, people are not dying on the streets. You don't see people dying on the streets." That's true. Because we do have - we go back to where we started - we have a right, a legal right to emergency care. And when the people get to emergency departments, whether the ambulance brings them, the police bring them, or their relatives bring them, they get care. We do care for them, whether they have insurance or not. And is that highly-valued right to emergency care actually working against attempts to reform the healthcare system? 
Maybe instead of looking at the healthcare system as a ship that needs stars, shinning or otherwise, to guide it, we should be looking at the ship itself. For the last twenty years I've argued that the American healthcare system has four major characteristics that we have to deal with in order to even talk about reform. Working on this presentation has helped me to think that it may be more fruitful to argue that the American healthcare system itself is a metaphor, a metaphor for America. It reflects America, and it tells us about Americans, about ourselves. We really exhibit all those characteristics ourselves and they reflect our country and its values.

We're technologically driven. We love technology, and we always want to be early adopters of new technology. We're spending more money on research for new medical technology, including new drugs and biologics, than all the other countries in the world put together. We're death denying; we absolutely, totally will not talk about death. That's not going to happen to us right? We're individualistic. We already saw that. We want our choice. We are the rugged individualists, right? We're the most individualistic country in the world. And we're wasteful, and we don't care. The only one of these four I think is easy to deal with - easy - is wastefulness. The market model with efficiency could tend to squeeze some wastefulness out. Individualistic, I don't think we will ever change. That's an essential part of being an American. So at least you're going to always have, thank God, the right to refuse treatment. We don't have the right to treatment, but at least we have the right to refuse treatment, no matter what our family thinks or what the doctors think. So that's good.

I want to spend most of the rest of my time on our fascination with technology and our desire to avoid even discussing death. Before I do, I want to think about other barriers to reform.

The title I used this morning in the companion speech to this one - at the medical center - was Best in the World. Uwe Reinhardt argues - and obviously I'm a major fan of Uwe - that one major reason we haven't been able to reform healthcare in America is that Americans believe that we have "the best" healthcare system in the world, so we shouldn't change it. Americans tend to believe everything we do is the "best in the world." Uwe was raised in Europe, so he's not as jaded as most people. He believes - and this is his example, so don't hold it against me - that if I had an elephant here and the elephant took a giant shit right here on the stage that Americans would sniff it and declare, "best in the world." No matter what it is, if it's ours, it's the best in the world and we're not going to change that. We're certainly not going to look at Europe or Canada or anywhere else to try to change our system because they have nothing to teach us because we're already the best in the world.

There's something to say for that reaction, and it's a lot like our reaction to Andrew Speaker - totally disconnected from any factual basis. For example, a national opinion poll two years ago showed that fifty-five percent of Americans are dissatisfied with their healthcare; forty percent say it's gotten worse in the last five years. On specifics, Americans know very little, and what 
they think they know is mostly wrong. More than 100,000 people a year are killed by medical errors in hospitals, but Americans think that the number is about 5000. So they think the system's much safer than it is, and they're still totally dissatisfied with that. So best in the world, depends what you mean by best. What's your measure of best?

In the most recent survey comparing Australia, Canada, Germany, New Zealand, the UK, and the U.S., the U.S. ranks dead last among those six countries in access, efficiency, equity, and healthy lives, and fifth in quality of care. At least we're moving up in quality of care. You all know the data on infant mortality and longevity; we're in the thirties and forties on those things. So what are we best at? That's a really good question to ask Americans if we are going to be able to say we're best in the world. If you ask, they'll say I don't know. Well, whatever they do, the Government will screw it up, right. Whatever we do, we don't want it to get worse. And for sure, we don't want "socialized medicine." So we are not going to get major healthcare reform simply by exposing facts. More than a change in knowledge is needed to move Americans to action in this arena.

So how do we do it? If you wanted to try to reform the system, how would you talk to your politicians? How would you have your politicians talk to the American people? I have previously suggested adopting the ecology metaphor, and emphasizing its core concepts like natural, quality (of life), sustainability, and conservation. But what if we are stuck with our current words and concepts? If you wanted to talk about security, you could talk about security. Security brings to mind two things immediately. The first is fear. We've seen that used over and over again. You can make Americans afraid of just about anything - except chickens. They're not afraid of them. You could also use security for safety. Sometimes we use the phrase going to be safe and secure, right? And for some reason - and I really don't know what this is - the patient safety movement really hasn't taken off. I mean, Don Berwick has done a terrific job. The Institute of Medicine has pushed it. I'm just surprised it hasn't become a centerpiece in American medicine. There are 100,000 lives, as Berwick has pointed out, you could relatively easily save every year. We like to save lives, but in this case we don't do it. So security is still a mixed metaphor. We have Homeland Security now. We seem to like that, though we don't know what that means, whether it's just anti-immigrant or whether it means something else. Security, I don't think is going to do it, even though I would certainly listen to Bill Clinton who knows that issue a lot better than I do. What about savings - savings for whom? Who's going to save? Somebody's going to save. Do we save by not spending money? Savings, I don't think is going to make much of a difference in the healthcare issue either.

Then there is the issue of quality - but quality of what? We've been arguing about the quality of our technology - we love technology - but not the quality of our lives. We all say it. I'm sure you say it too. If you're asked if you had a choice between quality of life and quantity of life, which would you take? I've never met anybody who wants an extra ten years in the nursing 
home, even an extra ten minutes in the nursing home. So we always say we want quality of life, the ideal life. Willard Gaylin, I'm paraphrasing, but I hope he won't mind, has suggested that for Americans the ideal death is when you're ninety-five, playing tennis with your mistress, and you suffer a fatal heart attack. I guess you could be playing with your wife too. The example means different things to different people, but the core of the idea rings true. The idea of a quick death, late in life, when you are still physically fit, is tough on your relatives but most people would say good for you, good for you. A long lingering death, stuck in a nursing home with bouts of dementia or progressive Alzheimer's disease is something that not many of us want, but that's where we're going. That's clearly where we're going. So we have to talk about quality of life and the role of the healthcare industry in promoting quality of life.

Responsibility is, as I've already suggested, a fundamentally un-American idea. We've tried to tell patients they're responsible for their own illnesses for years. They're not buying it. They don't care whether they weigh 400 pounds, never exercise, and smoke. If they get sick, Americans expect to be taken care of. That's it end of story, right? So in this presidential campaign there's a relatively new concept of "shared responsibility." It's a very unclear concept, like maybe we should all share this; we're all in this together. Almost looks like European solidarity, which has nothing to do with America and is unlikely to gain any political traction.

If you get beyond the rhetoric of shared responsibility in terms of health, essentially people with jobs are expected to pay their own health insurance and through their taxes pay other people's health insurance too. So it's hard to see who shares. Choice is a good thing but, as I've already suggested, we need to define what we mean, choice of what? Americans want choice of everything doctor, treatment, health plan, everything - and I don't think you can reform American healthcare without guaranteeing choice. That's why Hillary has moved choice up to number one on her list (replacing security there), and says, "If you like what you have, you keep it." It was John Edwards, by the way, who said that first. Both Hillary and Barack have picked up the Edwards position. You like the way it is? It's your choice. You get to keep it.

Simplicity, of course, you have to be kidding. No simplicity. That's gone. Just forget about that. Everything is complicated and likely to get even more complicated. The new magic term in healthcare is "mandate." What kind of metaphor or frame is mandate? If you Google the term you get its literal meaning, a date with a man. That makes a lot of sense, right? Remember single payer? Many people still want single payer. You may also recall that during the original debate on the Clinton plan, large numbers of Americans thought that single-payor meant that the health plan only covered single people. Words matter and the word "mandate" is too extreme for most Americans - at least that's my own perception. Americans don't like to be told what to do, don't like requirements, don't even like mandatory evacuations, as we've seen a number of times during the hurricanes in Florida, Houston, and New Orleans. Even though my state (Massachusetts) is famous for passing a mandate - and 
we're trying to figure out how to enforce it (and pay for it) right now - I don't think salvation lies in mandates or in using that term as a metaphor.

The three remaining presidential candidates are still mostly stuck with the 1994 rhetoric of health care reform, the democratic candidates with the original six (or five or six) Clinton navigational stars, and the republican candidate with an unapologetic market metaphor. Here's what the three major presidential candidates now have on their websites. This is not based on any personal discussion with them; this is on their websites. Here are the words and concepts they are using now to frame their healthcare reform positions.

Hillary Clinton has named her plan the "American Healthcare Choices Plan." She's got that through her head - choice, choice, choice. That's what killed the Clinton plan in 1994, and is not going to kill it again. Americans really do want choice. She's kept almost all of her other navigational stars as well - security, responsibility, and savings, which is now called "affordable."

Barack Obama has a "Plan for a Healthy America." He puts public health in there too, I guess, although the only major difference between the sketchy Hillary and Obama plans is the question of mandates and non-mandates. Barack seeks universal coverage by subsidizing premiums, Hillary by subsidizing premiums and requiring the uninsured to purchase insurance. But other than that Barack adopts the same basic language, using all of the original Clinton six stars, except responsibility. He also adds a few other specifics. He wants to use computerized medical records to modernize the system, and he wants to promote prevention.

John McCain supports the market metaphor and relies almost exclusively on using the market to change the system. He states that the way he's going to reform the system is by controlling costs. Cost is the biggest issue everywhere. All the talk about controlling costs - how's he going to do it? He's going to promote competition, back to the market metaphor, and maintain quality and provide access for all. At least he's got the right words - cost, quality, and access. He's back to the approach from thirty years ago talking about the three basic things. Still with the conceit, though, that you can improve all three simultaneously, that you can increase quality and access and decrease costs all at the same time.

So we have a long way to go before we will see healthcare reform. All of the candidates have a long way to go in framing this issue for the public to make it make sense, and they're doing it against this background, a country that is technologically driven and death-denying. And now I am, finally, back to these two pervasive characteristics, and I want to use a couple of what I think are fair but spectacular examples to illustrate how deep these two characteristics go in America. You may remember Barney Clark. This is the twenty fifth anniversary of Barney Clark's operation, when he became the first human being with a totally artificial heart. Overnight he became the most famous patient in the history of the world, with the possible exception of Lazarus. Barney's operation was called a medical miracle, or simply a miracle. We do have some religious connotations in our healthcare as well that are even more difficult to 
deal with than the sacred market. And Barney consented to this. It was hard. It was an experiment. But in the U.S. we don't really see a difference between experiments and therapy, so it was treatment, because he was dying, and there was nothing else that could be done to keep him alive.

I'll come back to artificial hearts in a second. The other pioneers of artificial hearts besides Bill DeVries and Robert Jarvik, are Michael DeBakey and Denton Cooley in Texas. You may remember that Cooley stole DeBakey's heart, which was meant to be a temporary bridge to transplant heart, and implanted it in Haskell Karp in 1979. And those two world-class surgeons did not speak to each other again until about two months ago when they had a reunion. And they're famous, again, because they're big-time surgeons and because they're technologically driven.

Two stories about these two guys, again, help illustrate America's problem with technology. The first relates to Dr. Cooley. When asked recently why in 1979 - when he did the first temporary artificial heart transplant - why he did it, he said, "I didn't want the Russians to beat us again like they did with Sputnik." In other words, Americans, not Russians, should be the world leader in technology - apparently whether the technology had any human usefulness or not.

The second story took place about a year and a half ago. Dr. DeBakey was at home, ninety-seven years old at the time, and he had terrible crushing pains, thought he was having a heart attack, and then he decided that - No - he was experiencing a dissecting aortic aneurysm. He's perhaps the world's expert on that diagnosis. He invented the surgical procedure to treat it. And he decided basically, "That's it. I don't want an operation, because I know the likelihood of me coming out of it with my brain intact is close to zero." So he signed forms stating, do not operate on me under any circumstances. He was able to stay home for a month and not die, and then he lost consciousness. The family then took him to the hospital and said, essentially, "Save his life." And they did. He's alive today, and his brain seems fine. This story illustrates how hard it is to die in America. Even though we say you have a legal right to refuse treatment, it is difficult to actually do it. Again, this is the most informed guy in the world saying he doesn't want treatment, and he gets it anyway. He's now the oldest survivor of a dissecting aneurysm operation in the world, ninetyeight years old. We look at that as what - best in the world? That's exactly right. Instead of horror, we react with admiration.

Robert Jarvik, the technologically-driven inventor of the artificial heart, the Jarvik-7, implanted in Barney Clark by William DeVries has lately embraced the market metaphor. Jarvik's been getting in a lot of trouble lately for acting as a pitchman in the direct-to-consumer Lipitor commercials, because some people consider it false advertisement. Not that he says anything that's not true about Lipitor, but that he portrays himself as a practicing physician. He doesn't say he prescribes Lipitor, doesn't actually even say he takes Lipitor. The problem is that he's not a practicing physician. He's never been a licensed physician, although he did graduate from medical school. He's an inventor. 
Remember the old ads, "I'm not a doctor but I play one on TV?" They worked because it's more important to play a doctor on TV than to actually be a doctor.

Jarvik - I actually like Rob - once told what I think is one of the great informed consent stories about DeVries, when asked how you get informed consent to the artificial heart. Never been done in a human being before, most likely to let you die a horrible, miserable death, more likely to prolong your dying than your life. And DeVries himself told me the story of Barney Clark's consent. He told me that he read the thirteen-page consent form aloud to Barney Clark twice, 24 hours apart, before he asked him to sign it. And he said, "I could have been reading from Don Quixote, and he would have still signed it." And that's a little frightening. What he meant by that is that Clark had read about the artificial heart in the press. Clark came to Utah to have it done from Seattle. You couldn't talk him out of it whatever you put in the so-called consent form.

Jarvik picks up the story after that, and he says, well, getting the first guy's consent is pretty hard. When you talk to the second candidate, he suggested, DeVries could say, "In my experience" this has worked very well. When you approach the third candidate, you can say, "In my series this has worked." And by the time you get to the fourth candidate, you can say, "In case after case after case." Rob comes to marketing honestly.

In addition to our love affair with technology, at some deep level we Americans really don't believe we have to die. We know we are going to die, but we are experts at avoiding death in discussions and in denying it. And there are extremes as well. In another life, I have debated members of a group that call themselves transhumanists. They really don't think humans have to die, but can instead become immortal post-humans through technology. They really think that we just need a little more information about physics and biology to literally live forever, close to human. Not as humans, not in these bodies, but as energy particles in the cosmos, or as immortal computer chips into which the contents of our brain has been transferred. Sounds like fun to me.

In any event, no matter what we actually believe, we act as if the major goal of medicine is to prolong life. If someone from another planet observed what we do with healthcare in America, they would likely conclude that we're trying to prolong life as long as possible, trying to extend the average life expectancy out to 150 years. Is that the right length of time? Or is there really no acceptable age to die no acceptable life expectancy. Are we all DeBakeys? Is our goal really an open-ended extension of life expectancy?

Public health has, by the way, increased your life expectancy. A lot of you know that for the last 130 years in the United States public health has increased your and my life expectancy seven hours a day every. Every day you live, you get another seven hours added to your life expectancy. That's pretty amazing. But is that good enough? Talk about quantity. Well, no, that's not good enough. We want quality of life too. We want a long life with good quality. Want to age in a teenage body. Good luck. Again, if you use the military metaphor, you may want everybody to have a robot body, indestructible steel 
plastic body where you can put your brain, maybe in a computer chip, put that in the robot body and that entity will "live" forever. Won't be quite you, but it would be a simulated you. Maybe we just plug you in. Plug your brain into a computer and you'll be dreaming, but you'll think it's real. Is that a reasonable goal for humans, a sort of personalized Matrix?

A more immediate example of the technologically-driven fight for more life that is being fought out in the courts, the FDA, and Congress, is access to investigational drugs by terminally ill patients. Personal stories dominate the public discussion, most prominently by a group called the Abigail Alliance. Abigail's story is as tragic as you can imagine: A nineteen-year-old dying of cancer with no treatments available, an experimental drug on the horizon, but she can't get access to it until the week before she dies. Would it have helped? God knows, but her father is convinced that it is essentially a crime to withhold it from a dying person. His position is that in this free country (free market?) people who are dying should have access to anything they want, at least anything that's past Phase 1, and at least if they can pay for it. That's the Abigail Alliance lawsuit. If the FDA thinks it could be safe, might be safe, safe enough to try in Phase 2 or Phase 3 experiments, then anybody whose doctor thinks it may be a reasonable thing to try should be able to purchase it and try it.

It's a very American argument, and thank God the court said no to it, there is no constitutional right to unapproved drugs, even for terminally ill patients. The FDA can require drugs to go through all three phases before they are cleared for marketing. On the other hand, the FDA does have a compassionate use program and other exceptions, so it's not quite true that you can't get access to unapproved drugs. The two judges in the minority, that thought that Abigail should have a right to access, used the self-defense excuse, and an American frontier metaphor. If you're dying, you should be able to defend your life, the way Americans did on the frontier. Self-defense is your right. What's more important than your life - life, liberty, and pursuit of happiness? You need life before you can do any of those. The argument, although it lost in this particular case, that Americans should have the right to do anything they and their doctor believe is important to do to save their life, really resonates in America.

Regulatory agencies, tamers of the free market, do not resonate - except perhaps, after market excesses have led to deaths or financial disasters. Americans are very ambivalent about government regulatory agencies, including the FDA, as we know. I said before we're death denying, but it may be more accurate to say we're ambivalent about death. At some point we know it's coming for us, or for our relatives. And the two cases that illustrate our ambivalence are Jack Kevorkian, who never, ever could be convicted of assisted suicide. Every jury that judged him for assisting in suicide thought it was fine until he actually killed somebody - then a jury decided that his actions were a serious legal violation. You can't actually kill people, even terminally ill people, Jack. But the fact that many people still take Kevorkian seriously tells us we have 
many continuing problems with the way we care for (and don't care for) dying people in this country, and we do.

The other case that is a favorite of mine is the case of Terri Schiavo. Terri Schiavo, and I feel a little strange using her first name, but like Karen Quinlan and Nancy Cruzan, and even Barney Clark, she has become as much a symbol as a real person, was the only patient that the U.S. Congress has ever called a special session to decide how she should be treated. The President cut short his vacation to sign the Terri Schiavo legislation just after Palm Sunday to "save" Terri's life. This is a woman who for ten years was in a permanent vegetative state, whose brain had atrophied to such an extent that almost nobody thought the damage could be reversible.

The guru of framing and metaphors, George Lakoff, told the Congressional Democrats at the time, you can't vote against the Terri Schiavo legislation, because Americans will label you as the party of death, Democrats, and you'll have to run next year against the party of life, the Republicans. I mean, it made some sense based on everything you know about Americans and their death denying beliefs, but it made no sense based on reality. As Senate Majority leader and physician Bill Frist has said he learned in retrospect, Americans don't want politicians to make treatment decisions for their loved ones. Well, why did Bill Frist ever think they did? I mean, who in the world ever thought that people writing a living will would stipulate, "If I'm ever not able to make a decision, I'm incompetent, I want my wife to go to Congress and ask the Congress and the President how I should be treated and let them decide." I mean, that's almost totally insane. And the other thing that turned out to be very interesting and, I'd like to think, predictable - but I won't go that far - is that eighty percent of Americans said they thought that the Congress was wrong to interfere, and that the decision should have been made - as it ultimately was - by her husband. Moreover, large majorities believe that his decision, based on what he believed she would have wanted, to remove the feeding tube, was the right decision to make, and they'd make a similar decision in their own family.

So we're not totally crazy after all. When our family members are dying, we understand that there are limits and should be limits, and we understand that treatment decisions should be mostly private decisions made in the doctorpatient relationship, not made in public or in the courts.

I want to again threaten to conclude with the image of a famous skull, photographed by Robert Mapplethorpe, very famous photographer who became controversial after he died in 1988 of HIV/AIDS. He'd done a lot of sexuallyexplicit photographs, but also photographs that tied sex and death together in a way that many Americans found disturbing and alluring in some senses. His photographs don't make you want to run out and kill yourself, but they do make you at least contemplate death, at least think about what you're going to look like in the future, after you die. For me certainly in the next thirty or forty years, probably much less than that, but I don't want to think about that - at 
least not right now. That's our future, and there's nothing healthcare can do about that.

We may not be permanent, but maybe we could make our bodies permanent. We have these body exhibits - I don't know if they've come to Indianapolis - but they have been all around the country. These plasticized human bodies, and nobody knows what to make of those. I don't either. I'm very conflicted about seeing real human bodies dissected and plasticized for public exhibition. I mean, it's incredible that you can see the beautiful and intricate anatomical detail. On the other hand, it's very disturbing to see human bodies used as objects of public display, like art objects. Their attraction-repulsion speaks to our ambivalence about death, and is not dispelled at all by any notion that the previous owners of these bodies might have consented to the display of their corpse.

My own view, after thinking about this for the last two decades, is that we should return to rights talk, and explicitly adopt the all-American rights metaphor for health reform. I think that's the only metaphor that's likely to ever resonate with Americans. Just as we have a right to emergency care, I think we have to expend more energy and imagination trying to generalize that right to a right to healthcare. One challenge, of course, is to define exactly what we mean by that. It's not going to be the same as the international right to healthcare, not the same as the right described in such detail as in Comment 14, but it's in that genre, in the rights ballpark, and I think we are fully capable of defining what we mean by basic, decent healthcare that every American should have a right to.

Hillary is not using that language on her website, but has used it in some of her speeches. She has declared, "Healthcare should not be a privilege. Healthcare should be a right." She used rights language, and I think that she's right to use rights language in this context. Obama may use it too, but I haven't heard him use it. I can guarantee you John McCain has never used the rights metaphor in this context.

It's like the right to education. I think we could explain that to Americans. Everybody has a right to education. We think that you cannot live a decent human life without an education, and you can't live a decent human life without having access to decent healthcare either. That should be part of what it means to be an American. Put another way, to change American healthcare we will have to change America itself - since healthcare is a mirror metaphor for America. The only plausible way to change America, at least in the short run, is to expand or redefine one of our inherent characteristics. Since death denial and technology fascinations have become part of our national ideology, it is unlikely that attacking them directly will yield results. We are a rights-based country, and increasing our rights, especially our individual rights, may be the most effective way to gain public support to make more than a marginal change in the present system.

I started with Susan Sontag, and I'll end with her. She is, I think, the person who knew the most about metaphors in medicine, who decried the mili- 
tary metaphor, the lack of limits, the over mobilization, the use of the body as a battlefield, and who herself beat breast cancer. In her personal "battle" with breast cancer she insisted on the most aggressive treatment, a radical mastectomy follow-up with intense chemotherapy. Thirty years later, likely as a result of the chemotherapy, she contracted myelodysplastic syndrome the untreatable precursor to fatal acute myeloid leukemia. She nonetheless determined that she would do exactly what she did with her breast cancer. She wanted everything done. She would not hear anybody - and very few people do - tell her it was incurable and that there was no treatment. She wanted everything.

Anyway, her son, David Rieff, describes his mother's last year of life in his book Swimming in a Sea of Death. Reviewers of the book have put it mildly: If there is a hard death, hers was one of the hardest deaths that anyone's ever endured. She was in constant pain and suffering for almost every hour of her last year of life. Except, her son says, for the last two or three hours of her life when she finally understood that there was nothing else that could be done.

My own point is not that Susan Sontag had a horrible death - she did have a horrible death - but she is, like DeBakey, the most knowledgeable patient there is, and an expert on the damage the military metaphor, combined with death-denial and technological wizardry, can do to real people. She really did know that science and medicine had nothing to offer her, that the only very slim possibility was in an incredibly painful and isolating bone marrow transplant, which she nonetheless endured. She clung to hope, even when there was none. The point is not to judge her, but rather to note that her's was an altogether American death, a death that we remain incapable of avoiding. If Susan Sontag and Michael DeBakey can't say no, neither can America.

Joan Didion entitles her own book about the death of her husband and her daughter, Magical Thinking. We all share magical thinking, but it's based on the notion that we don't really have to die - if we just did something. I'm going to be the exception. Yes, I know everybody dies, but I'll be the one person who doesn't die. It's not going to happen to me.

The only point is that we Americans get a lot out of the current healthcare system, and therefore making any meaningful change in it is going to be extraordinarily difficult. Even identifying the problems inherent in being technologically driven and death denying - and I really do believe they are inherent problems - does not take us anywhere near effectively addressing them. They're big problems, and they're very deeply rooted in the American psyche. So let me end (really) with another metaphor, a shipwreck. I said we're not sure whether reforming American health care will require a train wreck, bus wreck, or another type of catastrophe or collapse, but this is Gericault's famous painting, The Raft of the Medusa. It provides a fitting image on which to conclude our discussion of American healthcare reform. The painting is of the survivors on a raft constructed after their ship has sunk off the African coast. About 150 survivors cast off from the wreck on this raft. Others made it to shore on life boats. The painting is a representation of the survivors fifteen 
days later, when of the original 150 , only eighteen bodies remain on the raft, three corpses and fifteen live humans. All the others are dead, victims of mutinies, murders, cannibalism, of almost every horror known to human beings. In the painting there is a black man at the top (the ship was involved in the slave trade) who is signaling to a ship, which you can just barely make out on the horizon.

Julian Barnes has written eloquently about his thoughts on studying this painting: "How rarely do our emotions meet the object that they desire. How hopelessly we signal. How dark the sky and how big the waves." He continues, "We are all lost at sea, washed between hope and despair, hailing something that may never come to rescue us." I don't know if I want to go so far as to use that as a metaphor for American medicine today, but its close. I think we're all trapped between hope and despair. We'd like to think that there is something that's going to come and rescue the healthcare system, before it does implode, but we all know that it may have to implode before we can change it, because we are absolutely wed to technology and absolutely refuse to take our mortality seriously. Thank you very much.

I know we're over time, but I want to take one or two questions.

QUESTION: One more metaphor for you. That's the apocalyptical metaphor. That's what you have up there. The takeaway here is that a rational reform of the American healthcare system is essentially impossible until it implodes, if even then; correct?

MR. ANNAS: I'd like to think the answer's no, but I think that's true, unfortunately, yes. And why doesn't it implode? This is, again, Larry Brown's thing, because we do have this kind of safety net that allows us to not have people die on the streets. So we're not going to have a revolution. So we do take care, and we have the right to emergency care. Which is so bizarre, isn't it? That's, the most expensive, most last-ditch care there is, but we do have a right to that. I don't know. I wish I could have more.

Maybe we need a prophet. Hillary's been through it a lot, so maybe she could do it. Barack's like a prophet. Maybe we need a prophet. I don't know, but I wouldn't bet a lot of money on it. I wouldn't mortgage my house right now. I don't think it's going to happen this time because it's really expensive. Almost five percent of all the money that's spent in the entire world, on everything, is spent on healthcare in America, one dollar out of every twenty dollars. How can that possibly be? It's not as if that's the only thing we spend money on. We spend an incredible amount of money.

The other safety valve is medical tourism. It's also a type of safety net. People who can't afford care in the US go to India. I'm sure no one here ever thought in their wildest imagination Americans would go to India for healthcare. I don't want to say India's bad. India's not necessarily bad. But, we don't think of India as having cutting-edge technology in medicine. They do though. They can do it cheaper. They can do most operations for half or a 
quarter of what we can do it for. So Americans are going to India for healthcare. They're going to Mexico for healthcare too, because it's much less expensive than here, not because they think it's better there. It's cheaper there.

QUESTION: Where does trust fit into a national healthcare law? I know a lot of people don't trust the Government for healthcare when it can't even get a driver's license number correct or Social Security number correct.

MR. ANNAS: Well, they certainly can't be trusted to register your motor vehicle. I can tell you that. We were going to have them document organ donation on driver's licenses in Massachusetts, but the legislature said no, we can't do that. Trust is really important.

I talked a little bit about the military metaphor. One thing we don't use it for is to say that the Government should run healthcare the way the Government runs the military. Only the Government can raise an Army, only the Government can buy and control advanced weaponry, like nuclear weapons. So if we took the military metaphor seriously, we'd say, the Government should run medicine. Instead what we say - and McCain says this a lot, and so did my former governor, Mitt Romney, when he was running - we don't want a "Hillary Care," or, more generally, we don't want "socialized medicine."

No one's proposed socialized medicine - maybe they should - but socialized medicine is when the Government doesn't just pay all the bills, but owns the means of production, owns all the hospitals and clinics, and all the doctors and nurses are Government employees. That is what they have in England. That's what we have in the Veterans Administration. That's what we have in military medicine. It's not what anybody's proposing for the country, but at some point they will. It's like what Churchill said about America, that we'll come to the right decision but only after we've tried everything else. At some point we're going to come to the British system, the National Health Service, but we're a long way away from that. We first have to show that everything else doesn't work.

There are at least some analysts in Massachusetts that think that our mandate system, in which everybody buys their own health insurance, is just a step in the direction of Government providing insurance coverage for everybody. Once we show that it's impossible to actually mandate people to purchase insurance they can't afford, we're going to ultimately say we'll just cover everybody. I don't know if that's true or not, but at least it moves us in the right direction by significantly reducing the number of the uninsured. I don't want to argue against what my state is doing. At least it moves it in the right direction. We've covered another 300,000 people in Massachusetts, and that's good. The idea we're going to cover everybody seems unlikely.

The Government is involved in healthcare. This morning at the medical center, after discussion, one of the people said, well, maybe the way to frame it is not single payer, the way a lot of people do, like the Canadian system, but to talk about what Ted Kennedy's been talking about lately-Medicare 
for all. Most Americans are very fond of Medicare. You certainly can't take Medicare away from them. But they may want to change it and do it better. Doctors may want higher payment rates, and I don't blame them at all. Medicare is basically a very efficient system and Americans really like it a lot, and expanding Medicare may have more political attraction than creating any kind of new program.

There are really two ways to think about this, and this takes me back to my beginning days in this field, in the1970s. We think about two ways to get to national health insurance. One is by age, by just lowering the age of Medicare every few years and increasing it at the other end. Cover children and then cover people to twenty-one, then to twenty-four. So one way to change things is by age, being more and more inclusive. The other one is to go "disease by disease" to national health insurance.

I don't know if you remember the end stage renal disease program. In 1970, we decided we were going to cover everybody who needs renal dialysis, because it was so expensive and it was a lifesaver. We decided that we were just going to have national health insurance for renal dialysis. We still do, by the way. It's the only thing we have national health insurance for, because it turned out to be more than twenty times more expensive than imagined. So we didn't go disease by disease, and we don't cover children although we could still go age by age, but neither one looks like a likely path. 
